\title{
Knowledge and Attitude among Senior Dental Students on Forensic Dentistry: A Survey
}

\author{
${ }^{1}$ Govindarajan Sujatha, ${ }^{2}$ Jayanandan Muruganandan, ${ }^{3} \mathrm{~V}$ Vishnu Priya, ${ }^{4} \mathrm{~A}$ Thirumal Raj, ${ }^{5}$ Shaik M Shamsudeen
}

\begin{abstract}
Aim: To assess the knowledge and attitude among senior dental students in Chennai, India, on forensic odontology.
\end{abstract}

Materials and methods: A questionnaire-based study was conducted among 400 senior dental students across four colleges in Chennai. Fifteen questions were formulated and circulated.

Results: Majority of the population surveyed have reported to have received formal education in forensic odontology. However, most of them claimed to have inadequate knowledge due to lack of exposure pertaining to the scope, avenue, and importance related to this field.

Conclusion: The questionnaire survey has determined that though senior dental students have received some training in forensic odontology, they report that their knowledge is not adequate. They also felt that more importance to this field might improve the scope in India and abroad.

Clinical significance: There is a need for forensic dentistry to achieve its full potential, especially in India. Forensic odontologists serve as expert witnesses in the court of law for identification and investigation of crimes. This field, flourishing abroad, is still in an infant stage in India due to the lack of proper awareness among students, and probably not encouraged as much as the other clinical fields in dentistry.

Keywords: Forensic dentistry, Knowledge, Senior dental students.

How to cite this article: Sujatha G, Muruganandan J, Priya VV, Raj AT, Shamsudeen SM. Knowledge and Attitude among Senior Dental Students on Forensic Dentistry: A Survey. World J Dent 2018;9(3):187-191.

Source of support: Nil

Conflict of interest: None

\section{INTRODUCTION}

The term "Forensic" is derived from a Latin word "forensis": pertaining to forum. Forensic dentistry plays a major role in identification of man-made or natural disaster

\footnotetext{
1,2,4,5 Department of Oral Pathology and Microbiology, Sri Venkateswara Dental College and Hospital, Chennai, Tamil Nadu, India

${ }^{3}$ Department of Biochemistry, Saveetha Dental College and Hospital, Chennai, Tamil Nadu, India

Corresponding Author: V Vishnu Priya, Department of Biochemistry, Saveetha Dental College and Hospital Chennai, Tamil Nadu, India, Phone: +919841445599, e-mail: drvishnupriyav@gmail.com
}

events, which result in multiple fatalities that may not be identifiable through conventional methods, such as visual recognition or even fingerprints. This field has tremendous scope in areas of investigation. Developed countries have advanced training and employment opportunities, and almost every forensic laboratory has a forensic dentist. Nearly all dental schools offer forensic dentistry as a postgraduate program., ${ }^{1,2}$

Even though India offers various diploma and postgraduate courses related to forensic dentistry, an Master of Dental Surgery in forensic odontology has hardly been established in three places in India. The proposal for establishing such courses throughout India is gathering dust. As a result, most students have a negative attitude toward pursuing it as postgraduate due to lack of detailed exposure related to this field. The lack of recognition given to emerging forensic dentists by the forensic community also needs to change.

\section{MATERIALS AND METHODS}

A cross-sectional survey was conducted for analysis of knowledge and attitude toward forensic odontology. Questionnaires 1 comprising 15 questions were distributed among 400 dental students from four dental colleges in Chennai, India. The sample questionnaire is given below. The data were collected, tabulated, and statistically analyzed for frequencies and percentages by chi-square test using Statistical Package for the Social Sciences version 19.

\section{RESULTS}

Majority of the population surveyed have responded to all questions. More than 50\% have claimed to have received thorough training on forensic dentistry in their course. However, majority of them ( $>60 \%)$ feel that they do not have adequate knowledge, which might be due to the lack of practical exposure which deprived their confidence of handling cases. About $88 \%$ have not encountered any forensic-related cases so far, nor are they aware of legal issues related to the field (Graph 1).

Questions were also formulated to analyze the basic knowledge of students on forensic dentistry. Nearly $60 \%$ felt that clinical examination was alone required for age estimation; $42 \%$ were confident that they can perform age estimation in edentulous patients (Graphs 2 and 3). On being questioned on best deoxyribonucleic 
Questionnaire 1: Knowledge and attitude toward forensic dentistry among senior graduate students

Year of Study: Final Year/Internship

Gender: Male/Female

Q1. Have you received formal education in forensic dentistry in your course?
a. Yes
b. No
c. Can not say

Q2. Do you think you have adequate knowledge about forensic dentistry?
a. Yes
b. No
c. Can not say

Q3. Have you encountered forensic-related cases so far?
a. Yes
b. No
c. Can not say

Q4. How important do you think education on forensic dentistry in BDS course should be?
a. Very Important
b. Not Important
c. Can not say

Q5. Should there be a separate department for forensic dentistry?
a. Yes
b. No
c. Can not say

Q6. Are you interested in pursuing higher studies in forensic dentistry if offered?
a. Yes
b. No
c. Can not say

Q7. Are you confident of handling forensic dental cases?
a. Yes
b. No
c. Can not say

Q8. Are you aware of legal issues related to this field?
a. Yes
b. No
c. Can not say

Q9. How do you estimate dental age among your patients?
a. Clinical
b. Radiographic
c. Nothing specific

Q10. Do you read material related to forensic dentistry?
a. Yes
b. No
c. Can not say

Q11. What do you think is a best source of DNA in the oral cavity?
a. Saliva
b. Smear
c. Pulp

Q12. Which is the most common area of abuse?
a. Limbs
b. Head and Neck
c. Torso

Q13. Can you estimate the age of an individual in edentulous patients?
a. Yes
b. No
c. Do not know

Q14. What do you think is the best preserved soft tissue landmark for analysis?
a. Lip Print
b. Rugal Pattern
c. Tongue Print

Q15. Do you think our country should offer courses and jobs related to forensic dentistry?
a. Yes
b. No
c. Can not say

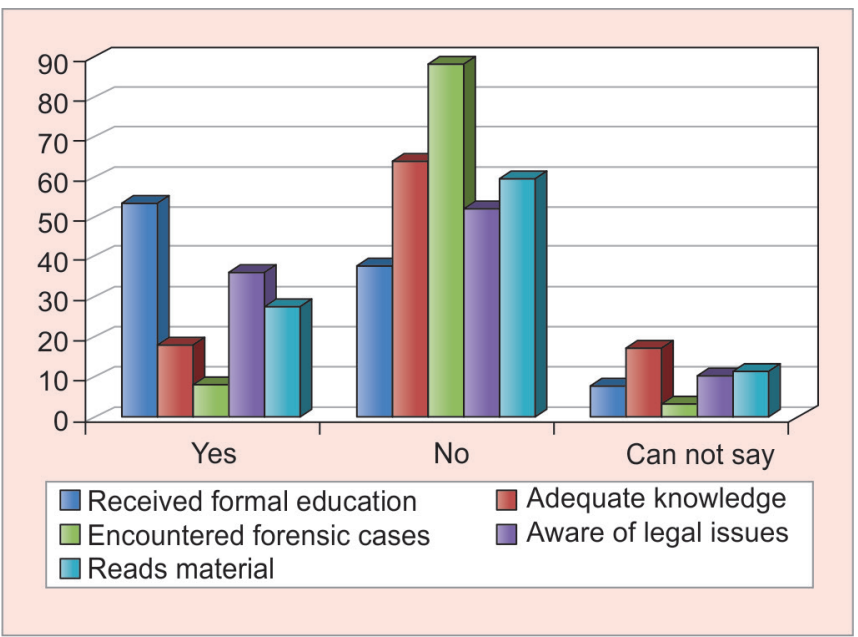

Graph 1: Knowledge-related answers

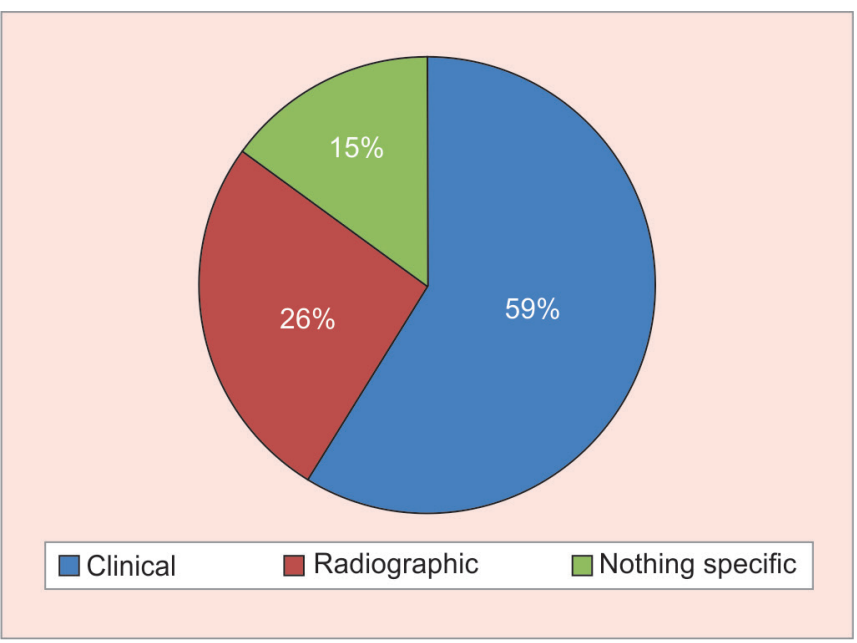

Graph 2: Response on best technique for age estimation 


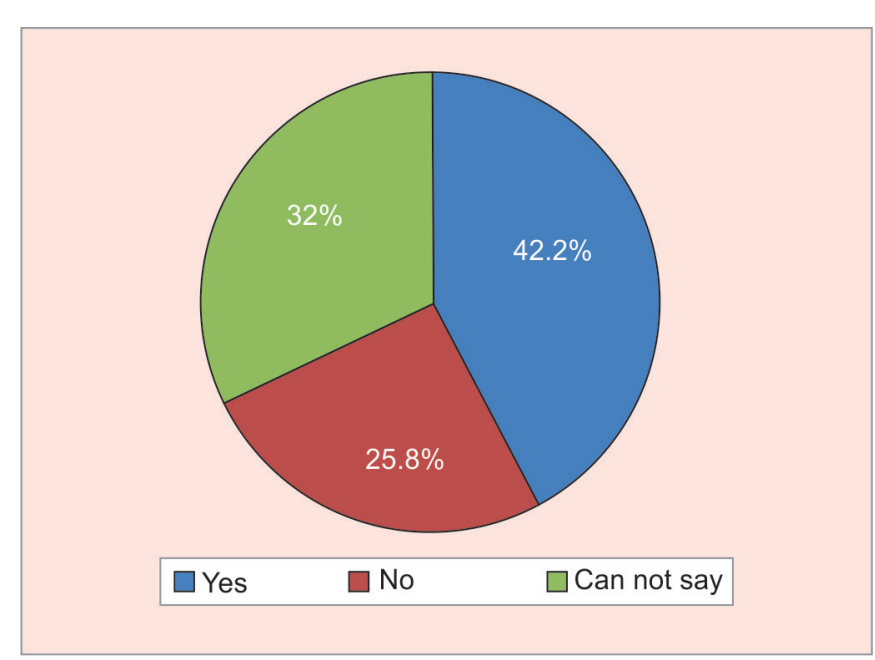

Graph 3: Knowledge of age estimation in edentulous patients

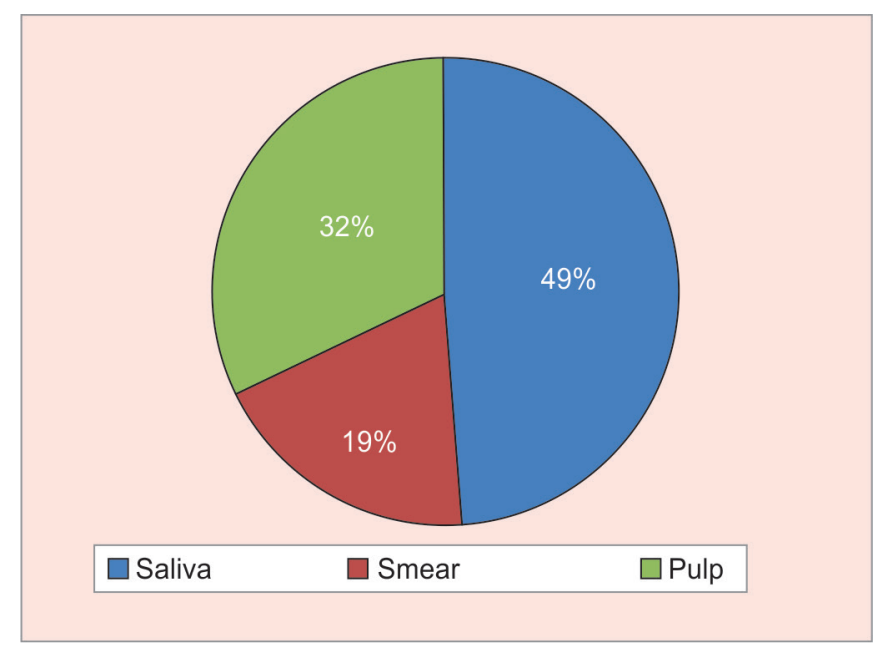

Graph 5: Response on best oral source for DNA sampling

acid (DNA) source in the oral cavity, majority of people answered it to be saliva. In an interesting observation, many respondents felt lip prints were best preserved landmarks for identification! Respondents believed that the most common area of abuse of individuals was head and neck region (Graphs 4 and 5).

To study forensic dentistry during graduation, $67.2 \%$ of the population surveyed feels that it is very important; $87.7 \%$ of the population surveyed felt that our country has to offer postgraduate programs on forensic odontology. However, only $48.8 \%$ was interested in pursuing forensics during higher studies. About $68.8 \%$ people feel there should be a separate department for it (Graph 6).

\section{DISCUSSION}

Forensic odontology has been defined by the Federation Dentaire Internationale as "that branch of dentistry which, in the interest of justice, deals with the proper handling and examination of dental evidence, and with the proper evaluation and presentation of dental findings."

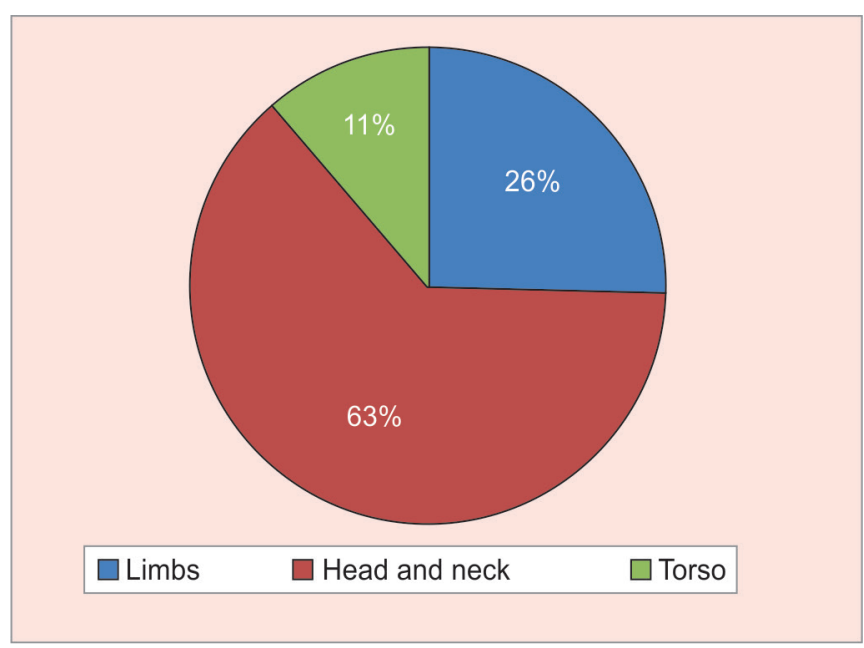

Graph 4: Response on most common body region suffering abuse

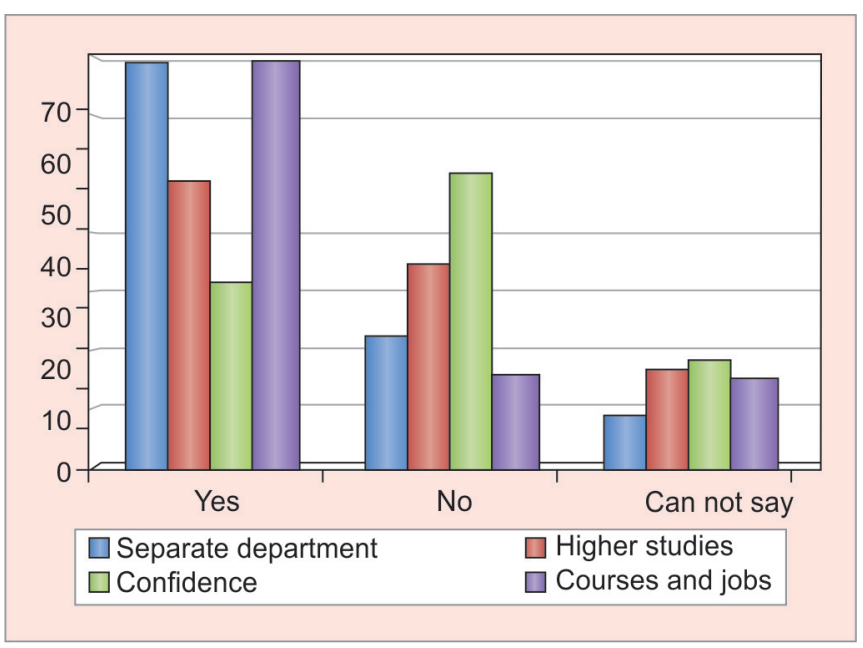

Graph 6: Responses on scope of forensic dentistry

Subcategories include bitemark analysis, dental anthropology, antemortem and postmortem identification and records, DNA analysis using oral tissues, and saliva analysis. This branch of dentistry and forensic science has been invaluable in many spheres of activity, especially in anthropology and crime investigation. ${ }^{1,2}$

There are numerous instances where forensic dentistry has aided criminal and disaster investigations. The 2004 tsunami of Asia where thousands were killed was an example, where dental experts contributed to the identification of the victims. Another well-known example is the assassination of Former Indian Prime Minister Rajiv Gandhi, where dental and facial analysis assisted in the identification of the assassin. The famous Ted Bundy case of 1978 was one of the earliest cases where bitemarks were conclusive in pinpointing the culprit. It is, of course, a moot point that, recently, the accuracy of bitemarks has been challenged and hence, courts no longer depend only on them as primary evidence. ${ }^{3,4}$

In developed countries, forensic odontology is a fascination among dentists, with greater exposure, avenues 
for specialization, greater availability of jobs, and recognition. In India, forensic odontology can be best described as a child, within the dental family, who shows a lot of promise but kept in place because of its age. Still, the past two decades have been encouraging, with the establishment of a separate Forensic Dentistry Department in a dental college in Dharwad, headed by arguably one of the foremost forensic dental experts Dr A Acharya. It is notable that Dr Acharya was the dental expert in the gruesome Delhi gangrape and murder case of 2012. ${ }^{5}$

Therefore, there is a huge potential for forensic dentistry in India. With no dearth of crimes, the only paucity is that of skilled forensic dentists. Therefore, the primary objective of our survey was to determine the knowledge and attitude of budding dentists regarding forensic dentistry.

Questions to assess the knowledge of forensic dentistry revealed that most of the respondents were able to answer correctly. However, the general trend was that the students seemed to have more of theoretical knowledge. The percentage of correct answers fell where the questions were centered on practical exposure.

The results of this survey basically indicate that the dental students are aware of forensic dentistry, and many have received training. This was in agreement with previous studies. 6

The dental curriculum does have forensic dentistry but there is an unconscious impression that it is not of academic (exam-wise) or practical employability. ${ }^{7}$

Previous questionnaire studies conducted in India and abroad have thrown up interesting observations. Rathod et $\mathrm{al}^{8}$ and Khare et $\mathrm{al}^{9}$ reported that awareness of forensic dentistry is very poor in cities and towns in India mainly due to lack of formal training. A survey of legal professionals concluded that they have adequate knowledge of the importance of dental evidence. However, specific knowledge of areas like rugal patterns, lip prints, etc., were not adequate. ${ }^{10}$ A 2016 survey of 400 police personnel revealed inadequate knowledge similar to legal professionals, but more worrisome is the fact that in $99.4 \%$ of cases forensic dentists have not been called to the crime scenes. ${ }^{11}$

A systematic review of 129 surveys in 2016 has determined that forensic dental awareness among dentists is still inadequate, and dentists should undergo more training in forensic odontology in their curriculum. The authors therefore, recommend a separate specialty. ${ }^{12}$

Sahni et $\mathrm{al}^{13}$ in their survey of dental teaching staff have reported that though there is basic knowledge of forensic dentistry, there is no incentive or job opportunity for upgradation in this field, which dampens the scientific interest. Balachander et $\mathrm{al}^{14}$ and Wadhwan et $\mathrm{al}^{15}$ have compiled a concise account of the evolution of forensic dentistry in the world and specifically in India. Our country especially needs a concerted effort to achieve the potential of this field. Therefore, the establishment of forensic dentistry as a medicolegal department in India is the need of the hour.

Even though there are classes, there is no practical exposure like a field trip to forensic departments, etc. Such activities may go a long way in improving the awareness of students. This survey is unique in that it reveals the impression among budding dental professionals of forensic dentistry and their perception of its future scope in India.

\section{CONCLUSION}

From our study, we observe that the main challenge in India is lack of exposure about the scope, importance, and avenue pertaining to forensic dentistry among undergraduate dental students. The material included in their present curriculum is inadequate according to the industrial standards as well as to build their curiosity and interest in the subject. Furthermore, we observe that with limited opportunities in the existing Indian postgraduate degree training programs, there is only a nonfunded research hampered by the lack of adequate infrastructure. As a result, dentists have to pursue their formal training in forensic dentistry from countries like the UK and Australia.

\section{REFERENCES}

1. Shamim T, Ipe Varughese V, Shameena PM, Sudha S. Forensic odontology: a new perspective. Medico-Legal Update 2006 Jan-Mar;6(1):1-4.

2. Senn, DR.; Weems, RA. Manual of forensic odontology. 5th ed. Boca Raton (FL): CRC Press; 2013.

3. Chandra Sekharan, P. The first human bomb-the untold story of Rajiv Gandhi assassination. Hyderabad: ALT Publications; 2008. [cited 2008 Apr 6]. Available from: https:// books.google.co.in/books?id=1z9OPgAACAAJ.

4. Hinchliffe J. Forensic odontology, part 4. Human bite marks. Br Dent J 2011 Apr;210(8):363-368.

5. Singh NN, Gowhar O, Ain TS, Sultan S. Exploring trends in forensic odontology. J Clin Diagn Res 2014 Dec;8(12):ZC28ZC30.

6. Preethi S, Einstein A, Sivapathasundharam B. Awareness of forensic odontology among dental practitioners in Chennai: a knowledge, attitude, practice study. J Forensic Dent Sci 2011 Jul;3(2):63-66.

7. Rajendran, R.; Sivapathasundharam, B.; editors. Shafer's textbook of oral pathology. 6th ed. India: Elsevier Pub; 2009.

8. Rathod V, Desai V, Pundir S, Dixit S, Chandraker R. Role of forensic dentistry for dental practitioners: a comprehensive study. J Forensic Dent Sci 2017 May-Aug;9(2):108-109.

9. Khare P, Chandra S, Raj V, Verma P, Subha G, Khare A. Status of forensic odontology in metro and in tier 2 city in urban India. J Forensic Dent Sci 2013 Jul;5(2):134-137. 
10. Selvajothi P, Lavanya C, Joshua E, Rao UK, Ranganathan K. Awareness of forensic odontology among legal professionals, Chennai, India. North Am J Med Sci 2014 Nov;6(11):553-557.

11. Pandit S, Desai D, Jeergal P, Venkatesh S. Awareness of forensic odontology among police personnel: a new ray of hope in forensic odontology. J Forensic Dent Sci 2016 Jan-Apr;8(1):56.

12. Gambhir RS, Singh G, Talwar PS, Gambhir J, Munjal V. Knowledge and awareness of forensic odontology among dentists in India: a systematic review. J Forensic Dent Sci 2016 Jan-Apr;8(1):2-6.
13. Sahni A, Rehani S, Mathias Y, Kardam P, Nagpal R, Kumari R. A questionnaire survey on forensic odontology: are we really aware? J Forensic Dent Sci 2016 May-Aug; 8(2):113.

14. Balachander N, Aravindha Babu N, Jimson S, Priyadharsini C, Masthan KM. Evolution of forensic odontology: an overview. J Pharm Bioallied Sci 2015 Apr;7(Suppl 1):S176-S180.

15. Wadhwan V, Shetty DC, Jain A, Khanna KS, Gupta A. A call for a new speciality: forensic odontology as a subject. J Forensic Dent Sci 2014 May;6(2):97-100. 